\title{
豚内臓に含まれるアラキドン酸含有リン脂質
}

\author{
井上 良計*1 - 林 雅弘 ${ }^{* 2}$. 恒吉 雅治*3 . 工藤 寛 ${ }^{* 3, * 4}$ \\ * 1 備前化成株式会社研究開発部 ( ₹709-0716 岡山県赤磐郡熊山町徳富 363) \\ * 2 南九州大学食品工学科（テ884-0003 宮崎県览湯郡高鍋町ひばりヶ丘） \\ * 3 宮崎県畜産試験場川南支場（广889-1301 宮崎県児湯郡川南町大字川南 21986） \\ *4 現宮崎県農政水産部農業経済課（T880-8501 宮崎県宮崎市橘通東 2 丁目 10-1)
}

\section{Phospholipids Containing Arachidonic Acid in Pig Internal Organs}

\author{
Yoshikazu Inoue ${ }^{* 1}$, Masahiro Hayashi ${ }^{* 2}$, Masaharu Tsuneyoshi*3 ${ }^{* 3}$ and Hiroshi Kudo ${ }^{* 3, * 4}$ \\ * 1 Research and Development Department, Bizen Chemical co., Ltd. \\ (363 Tokutomi, Kumayama-cho, Akaiwa-gun, Okayama-ken, 709-0716) \\ * 2 Department of Food Science and Technology, Minami-Kyushu University \\ (Hibarigaoka, Takanabe-cho, Koyu-gun, Miyazaki-ken, 884-0003) \\ * 3 Kawaminami Branch, Miyazaki Livestock Experimental Station \\ (21986 kawaminami, Kawaminami-cho, Koyu-gun, Miyazaki-ken, 889-1301)
}

\begin{abstract}
Examination was made of waste innards from livestock as a potential source of arachidonic acid (ARA). The internal organs of pigs slaughtered for meat production were analyzed for ARA content and distribution for this purpose.

Lipids were extracted from tongues, stomachs, small and large intestines, livers, spleens, hearts, lungs, bladders, ovaries, uteruses and kidneys and ARA was found present at 1.5$19.2 \%$ in total fatty acid. Lipids extracted from livers and spleens were particularly high in ARA at $19.2 \%$ and $18.5 \%$, respectively. ARA in these organs was mainly distributed in phospholipids, especially phosphatidylethanolamine (PE). In PE of livers, ARA in the total fatty acid was $23.3 \%$.
\end{abstract}

Livers and spleens of pigs would thus appear potential sources of ARA for food additives. ARA in lipids of pig internal organs was distributed primarily in PE whose absorption and physiological function are superior to triacylglycerins.

Key words : arachidonic acid, liver, spleen, phospholipid, pig

\begin{abstract}
1 緒 言
アラキドン酸（ARA）は種々の生理活性を持つこと が知られているが，近年では乳児や未熟児の発有に対す る必須性が注目されている(1) 6)。さらに，FAO/WHO などの公的機関が攝取推奨量を公表したことから7), 乳 児用調製粉乳への添加が検討され始めている ${ }^{8)}$ 。現在の ところ, 食品添加物としての ARA の安定的な供給源は 卵黄レシチンであるが ARAの含有量が低く，さらに ARA 高含有量の供給源が求められている。また糸状菌 による ARA の微生物生産も古くから検討され ${ }^{9) \sim 11)}$, 糸
\end{abstract}

連絡者：林 雅弘
状菌由来の ARA 含有油脂の食品への利用が欧州では検 討されつつあるが，日本国内では未だ実用化には至って いない。

一方，宮崎県の肉豚出荷頭数は鹿児島県に次いで全国 第 2 位であり ${ }^{12)}$ ，養豚業は宮崎県内の主要産業となって いる。しかし，1996 年夏の病原性大腸菌 O-157 による 集団食中毒多発事件以来, 畜産物, 特に内臟類（畜産副 生物）の食用としての消費は大きく落ち込んでいる。現 在では県内で発生する畜産副生物の一部はペットフード などに利用されているが，その大半は利用されることな く廃呆処分されているのが実状である。

本研究は未利用資源である畜産副生物の有効利用の一 環として, 豚内臓脂質の食品添加物としての利用可能性 
を検討するため, 豚内臓中の ARA の分布および存在形 態について明らかにし，未利用資源の有効利用の可能性 を見いだしたので報告する。

\section{2 実験}

$2 \cdot 1$ 試 料

試料は宮崎県畜産試験場川南支場にて, 市販配合飼料 で体重 100 110 kg まで慣行の方法で飼育した肥育豚

(WL $\times \mathrm{D}$, 生後 160 日齢前後) の内臓を用いた。屠殺 直後の肥育豚より内臟摘出後, 直ちに氷冷下で細断し, ミンチにして凍結乾燥後, 分析試料とした。

\section{$2 \cdot 2$ 脂質抽出および分画}

凍結乾燥・粉砕した試料より, Folch 法により総脂質 （TL）を抽出した ${ }^{13)}$ 。得られた TLをシリカゲルを用 いたカラムクロマトグラフィーにて中性脂質 (NL) と リン脂質 $(\mathrm{PL})$ を分取した ${ }^{14)}$ 。さらにPLを薄層クロ マトグラフィー（TLC）により展開し（展開溶媒 クロ ロホルム : メタノール $: 7 \mathrm{~mol} / \mathrm{L}$ アンモニア水, $13: 6$ : $0.8 \mathrm{~V} / \mathrm{V} / \mathrm{V}), \mathrm{I}_{2}$ 蒸気にて発色後, 主要なスポット部分 を搔き取って,クロロホルム/メタノール $(2: 1, \mathrm{~V} / \mathrm{V})$ で抽出し, 各リン脂質画分を脂肪酸分析に供した。

\section{$2 \cdot 3$ 脂肪酸分析 ${ }^{15)}$}

試料より抽出・分画した各フラクションを $10 \%$ 塩化 水素一メタノール溶液にてメタノリシスの後, キャピラ リーガスクロマトグラフィー（GLC）で脂肪酸組成を 分析した。GLC 分析条件は以下の通り。

ガスクロマトグラフ : GL サイエンス GC 363

カラム : 信和化工 HR-Thermon-3000 B $0.25 \mathrm{~mm} \times 30 \mathrm{~m}$ カラム温度 : $150 \rightarrow 220^{\circ} \mathrm{C}\left(2^{\circ} \mathrm{C} / \mathrm{min}\right)$

キャリアーガス: $\mathrm{He}\left(1.5 \mathrm{~kg} / \mathrm{cm}^{2}\right)$

検出器 : 水素炎イオン化検出器 (FID)

\section{3 結果及び考察}

\section{$3 \cdot 1$ 各臓器の TL 含量及び ARA 含有率}

分析した各臟器の TL 含有量と総脂肪酸 (TFA) 中 の ARA 含有率を Table 1 に示した。臟器中の TL 含有
量は子宮の $4.9 \%$ から大腸の $47.8 \%$ まで, 臟器間で大 きく異なった。また, 各臓器の TFA 中の ARA 含有率 は胃・大腸など TL 含有量の高い臟器で低く, 肝臟・脾 臓で約 19\% と比較的高い値を示した。

ARA 供給源としては TL 含有量が高く, かつ TFA 中の ARA 含有率が高い事が望ましいが，その点からは 今回分析を行った臟器では肝臓及び脾臟が ARA 供給源 として有望と考えられた。また，1頭あたりの藏器重量 が大きいことも資源利用の点から重要で，この点では小 腸も利用可能であると考えられた。

\section{$3 \cdot 2 \mathrm{TL}$ 中の NL/PL 比及び ARA の分布}

各臟器の NL/PL 比をみると胃, 大腸, 舌など TL 含 量の高い臟器では TL 中の NL の比率が高く, 高 TL 含 量はNL の蓄積によるものであることがわかる（Fig. 1)。

また，NL およびPL 中の ARA 含有率をみると，子宮 を除いたいずれの臓器においても PL 中の脂肪酸で ARAの含有率が高かった（Fig. 2)。すなわち, 高 TL 含量を示す臓器は飽和脂肪酸を主たる構成脂肪酸とする NL を著量含有しており，ARA あるいは ARA 含有リン 脂質の供給源としては望ましくないことが示唆された。

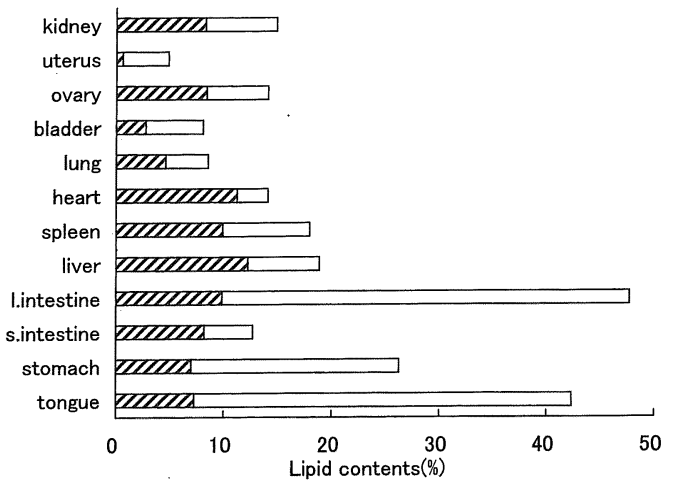

Fig. 1 Lipid Contents in the Internals of Pig. (\%, dry basis)

$\square \mathrm{PL} \quad \square \mathrm{NL}$

Table1 Fatty Acid Compositions of the Total Lipid in the Internals of Pig. (\%)

\begin{tabular}{lrrrrrrrrrrrr}
\hline & tongue & stomach & $\begin{array}{l}\text { small } \\
\text { intestine }\end{array}$ & $\begin{array}{l}\text { large } \\
\text { intestine }\end{array}$ & liver & spleen & heart & lung & bladder & ovary & uterus & kidney \\
\hline C14:0 & 1.2 & 1.0 & 0.4 & 1.5 & 0.2 & 0.2 & 0.2 & 1.2 & 1.1 & 1.5 & 0.6 & 0.5 \\
C16:0 & 25.1 & 24.7 & 21.7 & 28.9 & 11.7 & 11.8 & 14.5 & 33.3 & 27.1 & 27.5 & 22.8 & 23.4 \\
C16:1 & 2.0 & 1.3 & 0.5 & 1.7 & Tr. & Tr. & 0.3 & 0.2 & 1.7 & 0.7 & 1.1 & Tr. \\
C18:0 & 11.4 & 21.1 & 12.9 & 20.4 & 29.8 & 30.2 & 11.1 & 14.0 & 16.6 & 13.7 & 12.6 & 13.8 \\
C18:1 & 49.1 & 35.4 & 20.3 & 34.5 & 11.5 & 11.5 & 14.7 & 27.1 & 39.0 & 22.6 & 15.9 & 20.7 \\
C18:2 & 8.2 & 10.6 & 14.6 & 8.4 & 17.1 & 17.3 & 29.4 & 7.6 & 7.0 & 6.7 & 5.5 & 13.5 \\
C20:4n-6 & 1.5 & 2.7 & 9.5 & 1.5 & 19.2 & 18.5 & 12.1 & 7.8 & 4.7 & 15.7 & 13.7 & 16.4 \\
\hline Total lipid $^{*}$ & 42.4 & 26.3 & 12.7 & 47.8 & 18.9 & 18.0 & 14.1 & 8.6 & 8.1 & 14.1 & 4.9 & 14.9 \\
\hline & & & & & & & & & & & & $* \%$, dry basis
\end{tabular}




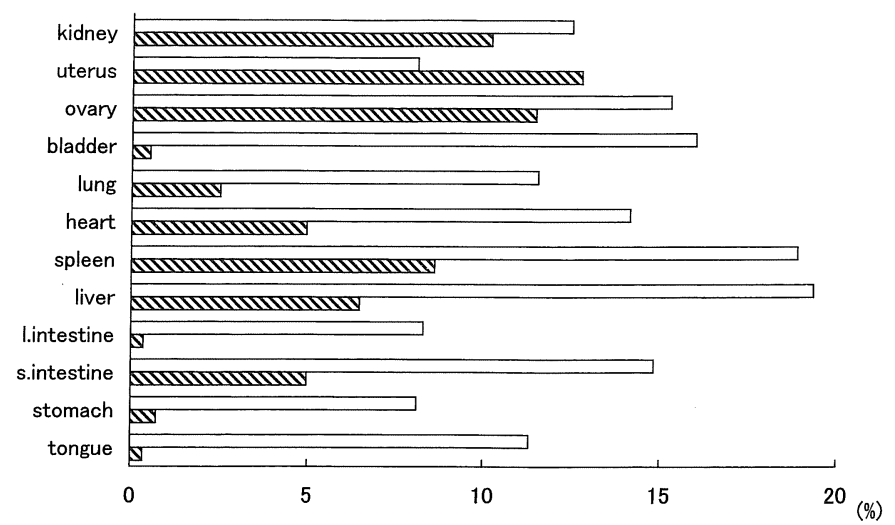

Fig. 2 ARA Contents in the NL and PL of the Inter nals.

$\triangle \mathrm{ARA} \%$ in the NL $\square \mathrm{ARA} \%$ in the PL

一方，TL 中の ARA 含有率の高かった肝臓，脾蔵では 特に PL 中に ARA 含有率が高く，これらの臓器の利用 の可能性が高まった。

\section{$3 \cdot 3$ 主要なリン脂質中の ARA 含有率}

豚 1 頭あたりの臓器重量も大きく, ARA 供給源とし て有望と思われる肝臓や脾蔵について PL の TLC 分析 を行った。肝臓 PLの主要成分はホスファチジルコリン (PC) とホスファチジルエタノールアミン (PE) であ り，そのPL中の含有量はそれぞれ $30.6 \%$ おび $14.2 \%$ であった。しかし脾蔵においては，PL 中の PC 及び PEの占める割合は肝臓と異なり，それぞれ $18.9 \%$ および $27.4 \%$ と，PEの方が多く含まれていた。また， $\mathrm{PC}$ と $\mathrm{PE}$ を構成する脂肪酸中の $\mathrm{ARA}$ 含有率をみると, $\mathrm{PC}$ 中には肝臓で $7.7 \%$, 脾臓で $4.8 \%$ であったのに対 し，PE中には肝臓で $23.3 \% ，$ 脾臓では $23.7 \%$ と， ARA はPE 中に多く分布していた（Fig. 3，4）。

多価不飽和脂肪酸（PUFA）の生理機能については膨 大な知見が蓄積されつつあり，近年ではその知見に基づ いて機能性食品・医薬への応用が現実のものになりつつ ある。一般食品への応用では $\mathrm{n}-3$ 系 PUFA の利用が進

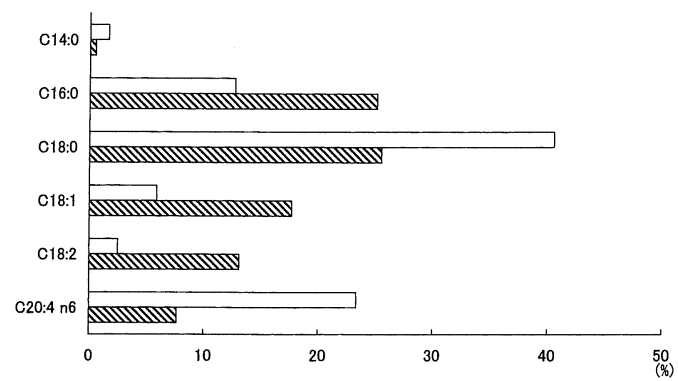

Fig. 3 Fatty Acid Compositions in PC and PE of Liver.

$\mathrm{Q}$ in $\mathrm{PC} \square$ in $\mathrm{PE}$
む中，ARA などの n-6 系 PUFA についてはまだ今後の 課題であるといえる。しかしながら近年では，n-3 系 PUFA も含め, PUFA-PL の生理機能に研究の焦点が あてられ，トリアシルグリセリン（TG）型にない生理 機能が次々に明らかにされる中，安定的な供給源が探索 されている。これまでにEPA-PL P DHA-PL がバク テリアに含まれるという報告 ${ }^{16)}$,17) P DHA-PL の供給源 としてイカ内葴の利用の可能性を検討した報告 ${ }^{18)}$ がある が, ARA-PL については供給源が卵黄レシチンに限ら れ，TFA 中の ARA 含有率はせいぜい数\%程度にとど まっていた ${ }^{19)}$ 。

動物肝臓中にARA が含有されることは以前から知ら れていたが20) 22)，ARA-PLの供給源として着目し，そ の可能性を示したのは本報告が初めてである。平成 5 9 年度における宮崎県の肉豚出荷頭数は年間 130 万頭あ まりであるが ${ }^{12)}$ ，内臓類の発生量は年間 $18,000 \mathrm{t}$ 以上 であると推定され，その有効利用が期待される。また， 動物の脳には同様に ARA が高含有量で含まれると考え られるが，本研究の目的は ARA-PLの食品への利用で あるため，プリオン等の食品衛生上の問題を抱える脳に

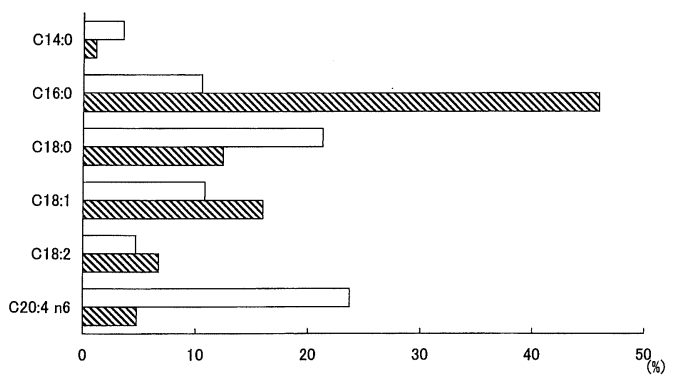

Fig. 4 Fatty Acid Compositions in $\mathrm{PC}$ and $\mathrm{PE}$ of Spleen.

$\mathbf{Q}$ in $\mathrm{PC} \square$ in $\mathrm{PE}$ 
ついては実用化が困難と考元, 分析対象外とした。結果 として，従来食用に供されてきた豚肝臓，小腸に新たな 利用の道を見いだした。また，脾藏については現在全く 利用されておらず，未利用資源の有効利用の可能性を見 いだした。

今後, 各臟器中の ARA-PL の精製, 安定性なぞ応用 面での研究に加え, ARA-PL に特徴的な生理活性の探 索が必要である。

\section{謝辞}

本研究を行うにあたり，分析試料のサンプリングに御 協力いただいた宮崎県畜産試験場川南支場の皆様, およ び統計資料収集に御協力いただいた，同支場養豚科の広 津美和技師に深謝いたします。

（受付：2000 年 2 月 17 日，受理：2000 年 4 月 4 日）

\section{文献}

1) M.A. Crawford, W. Doyle, P. Drury, A. Lennon, K. Costeloe, M. Leighfield, J. Int. Med, 225, 159 (1989).

2) A. Lucas, R. Morley, T.J. Cole, G. Lister, C. Leeson-Payne, Lancet, 339, 261 (1992).

3) C.I. Lanting, V. Fidler, M. Huisman, B.C.L. Touwen, E.R. Boersma, Lancet, 344, 1319 (1994).

4) B. Koletzko, T. Decsi, H. Demmelmair, Lipids, 31, 79 (1996).

5) R.A. Gibson, M. Makrides, Acta Pediatr, 87, 1017 (1998).

6) E.E. Birch, D.R. Hoffman, R. Uauy, D.G. Birch, C. Prestidge, Pediatric Research, 44, 201 (1998).
7) M. Ono, M. Hosokawa, Y. Inoue, K.Takahashi, JAOCS, 74, 1415 (1997).

8) 米久保明得, 食品と開発，31, No.6, 17 (1997).

9) H. Yamada, S. Shimizu, Y. Shinmen, Agric. Biol. Chem., 51, 785 (1987).

10) Y. Shinmen, S.Shimizu, K. Akimoto, H. Kawashima, H. Yamada, Appl. Microbiol. Biotechnol., 31, 11 (1989).

11）清水 昌, 化学と生物, 31, 312 (1993).

12）九州農政局宮崎統計情報事務所編，“平成 10 年宮 崎県畜産統計”宮崎農林統計協会 (1999).

13) J. Folch, M. Lees, G.H. Sloanestanley, J. Biol. Chem., 226, 497 (1957).

14）藤野安彦, “脂質分析法入門” 学会出版センター (1978) p.69.

15) M. Hayashi, K. Toda, S. Kitaoka, Biosci. Biotech. Biochem., 57, 352 (1993).

16) K. Watanabe, C. Ishikawa, K. Yazawa, K. Kondo, A. Kawaguchi, J. Mar. Biotechnol., 4, 104 (1996).

17) K. Watanabe, C. Ishikawa, I. Ohtsuka, M. Kamata, M. Tomita, K. Yazawa, H. Muramatsu, Lipids, 32, 975 (1997).

18) C. Deng, K. Watanabe, K. Yazawa, S. Wada, Food Res. Int., 31, 697 (1998).

19) 長谷川峯夫，“卵の科学”朝倉書店 (1998) p.64.

20) 秋元健吾, 食品と開発, 32, No.6, 14 (1998).

21）古泉 祳, 鈴木嘉彦, 志村純子, 劉 昌宇, ビタ ミン, 69, 547 (1995).

22）北田善三，佐々木美智子，上田保之，大口龍太郎， 弓場秀雄, 日本食品工業学会誌, 32, 219 (1985). 


\section{[ノート］＼cjkstart豚内臓に含まれるアラキドン酸含有リン脂質}

井上良計 ${ }^{* 1}$ ・林 雅 弘 ${ }^{* 2}$ ・恒 吉 雅 治*3
*1 備前化成株式会社研究開発部 ( $\bar{T} 709-0716$ 岡山県赤磐郡熊山町徳富 363)
*2 南九州大学食品工学科（† 884-0003 宮崎県児湯郡高鍋町ひばりヶ丘）
*3＼cjkstart宮崎県畜産試験場川南支場（广 889-1301 宮崎県児湯郡川南町大字川南 21986）
*4＼cjkstart現宮崎県農政水産部農業経済課（干 880-8501 宮崎県宮崎市橘通東 2 丁目 10-1）

未利用資源である家畜内臓の有効利用を推進するため，豚内臟のアラキドン酸（ARA）供給源としての利用可 能性を検討した。肥育豚の舌，胃，小腸，大腸，肝臓，脾臟，心臓，肺，膀脱，卵巣，子宮，腎臓から抽出した 総脂質の脂肪酸中に ARA は $1.5 \sim 19.2 \%$ 検出された。特に肝臓と脾臓に ARA が豊富に含有されており，その ARA はリン脂質，なかでもホスファチジルエタノールアミンに多量に分布していた。

豚内臟に含まれる ARA が吸収性や生理活性の点からトリアシルグリセリンより優れるとされるリン脂質の形 で含まれることが明らかとなり, 食品衛生上，安全でかつ安定供給可能な未利用資源からの ARA 供給が期待さ れる。

(連絡者：林 雅弘) Vol.49, No.7, 723 (2000)

\section{[ノート］エノコログサ属植物に含まれるステロールの ガスクロマトグラフィーによる定量}

高津戸秀・系川恵美子、阿部文一・鳴海安久 上越教育大学自然系化学教室

（テ 943-8512 新潟県上越市山屋敷町 1)

エノコログサ属植物に含まれるステロールのガスクロマトグラフィーによる定量を行った。アワ (Setaria italica）では, シトステロールは種子, 葉, 茎及び根の各器官においても最も多く含まれていた。また, シトスタノー ルは種子に局在し，スティグマステロールは葉及び茎に局在していた。エノコログサ (S.viridis)，オオエノコロ (S.X pycnocoma) 及びキンエノコロ (S.glauca) についても種子, 葉, 茎の器官別にステロール含量を解明した。 シトスタノールはこれら 3 種において，アワよりは少ないながらも検出された。オオエノコロの種子，葉，荎に おける主要植物ステロール（カンペステロール，スティグマステロール及びシトステロール）の含量はアワのそ れと良く似ていた。キンエノコロとエノコログサでは, 葉及び茎での主要ステロール含量は種子と比べて著しく 少なく, アワやオオエノコロの葉及び茎の主要ステロール含量とは大きく異なっていた。同じイネ科エノコログ サ属植物において，このような相違点が見られたことは化学分類的に興味深い。

（連絡者：高津戸 秀） Vol.49, No.7， 727（2000） 